$1>x$.

\section{3. 迴轉性啳眼球墨湢八检討}

星 野 貞 次(亭 蒂 迴轉性後眼球震琱八現今最モ弘ク行ハレ且ツ 主姴ナル前庭迷路機能ノ一检查法デアル。身體 ノ呬轉二ヨリ刺戟七ラレタル前庭迷路，與鹪カ ラ苾起七ラル、反射性，眠球運動 7 質量的二計 湖シタ成績 $コ リ$ 迷路機能ノ態度 7 歸納シ刵定二 供シテ居ルノデフル。周知ノ如り䛜轉性後服震 八迴轉ノ方法. 時間及ビ㑑人卦其他諸種，要約 =ヨリ其出現程度八異ナルノデアルガ. 多数先 進擧者ノ調ベニヨリ略タ或ル一定筙園内ノ眠震 持緮時閒ア以テ正常ト看做サレテ居ル・ソシテ 該籁園以下若クハ以上 7 機能低下若ク八機能立 進トシテ病的卜看做シテ居ル。事實吾人ノ日常

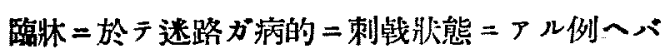
內耳炎. 內耳出血等二斯持續時閒八檑大延長

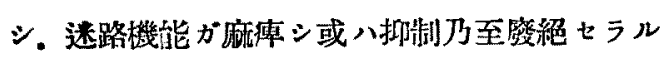

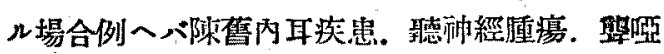
等タ。其持續時間が短小乃至消失スル，八凬二 認容サレテ居テ 之二關シテハ何等疑菚ノ挾ム

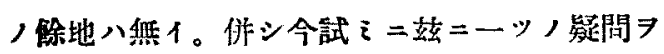
設定シテ見十ウ。夫レハ一般生理學的現象ナル モノ、本質カラ，見方デアッテ，呬轉後作震ナ

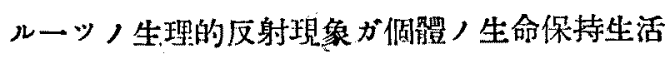
遂行二如何ナル合目的性，意䉝ガフルカー就テ

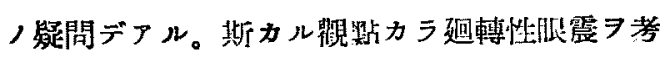
ヘテ見ル。先ヅ身體趈轉中二出現スッ服震八身

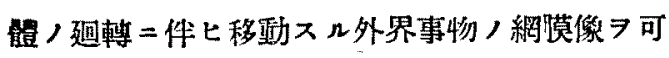
及的二固定セシメントスル作用卜，迅速二轉举

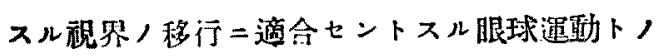
聯合デナッテ 失ハレントスルモノタ整ベント スル明カ $=$ 均街生理上/意笔
ル. 次二䢙轉习停业七ル後二於テ八外界，事物 八眼球二對シテ相麗的ノ移動八停止サとテ居 几。眼球八最早視界，移動 ク消失シテ居几。夫レニモ拘ハラズ䞮轉停止後 二尚水恰モ外界事物/移動アルガ如ク二眼球運

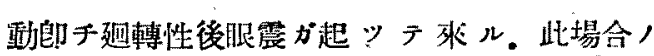

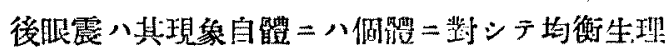
上ノ合目的性 7 認又難 體八外界/物象，廻轉䜌 7 其生理上毫モ必要卜 セメノデアッテ 只迴轉中二惹起セラレタ眼震 ノ影響が廻轉停止後二發現スルモノト認メルノ 外ナ1。夫レガ前庭器/暴造カラノ理學的現象 力或八其他，原因カラ，孰レニ七ヨ呬轉性後腿

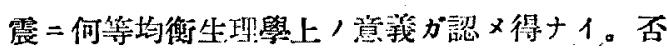
夫レノミナラズ身骴均衡上カラ八却ツテ不都合 ナ其目的二沿バ邪限ナ現像デサヘフルソデ

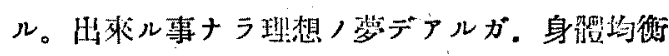
作用上二八廻轉性後服震八無キ二如カズデ ア ル。上述，廻轉性後服震＝關ス几余等，見解八 元ョリ今後/批制＝俟ツトシテ現富，問題卜 シテ人間ノ身澧均衡機能が爾が上ニモ向上七シ メル事が强ク要㘹セラル、秋二常ツテ健民强兵 醫學,立場カラ八均衡保持二不都合ナル後服祳 八之ラ減少乃至消減セシメ度ク思フ、斯カル䚋

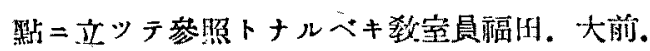
本庶. 岩波其他諸氏, 研究概要 7 示說シ. 終リ

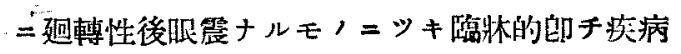

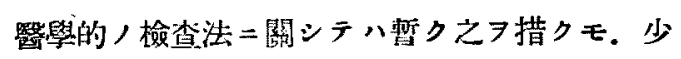
クトモ優レタル均衡機能保持者ノ養成延1テ其 選拔二當りテハ從來，迥博性啳服震二對スル見 解 7 根本的二改ムル，哭緊ナルヨ提議スル。

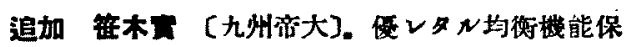
持者/黄成二關入N提議八國家的ノ重大意藏有入 